\title{
HANNAH ARENDT ON THE RELATION BETWEEN MORALITY AND PLURALITY ${ }^{1}$
}

\begin{abstract}
In this article, we examine, in the light of Arendt's categories, the fundamental structure of traditional claims on moral life. In other words, we evaluate the spirit in which traditional morality relates to the human world, especially, to the human condition of plurality. In this way, we shall be led to a perceptive reading of Arendt's groundbreaking view on morality and its borderline possibility of assuming a paradoxically significant role in the worldly affairs.
\end{abstract}

Keywords: Arendt, Plato, Socrates, morality, plurality, thinking.

\section{1}

We are "naïve" if we keep our faith in morality without recourse to an absolute as its source of legitimacy; for, according to Friedrich Nietzsche whose famous aphorism we have just paraphrased, this "beyond" is absolutely necessary. ${ }^{2}$ But the human tendency to appeal to a "beyond" whatsoever in order to justify moral conduct has just been restrained by the fact that "God is dead" or, in other words, that the philosophers' "true world" has been abolished. ${ }^{3}$

Now, if "God is dead," what would actually serve as a pattern of Man's image and conduct? Furthermore, speaking in terms of Kant's moral philosophy and, thus, outside the Christian framework of reference, with the collapse of

\footnotetext{
${ }^{1}$ I would like to express my gratitude to Alexander S. Onassis Public Benefit Foundation. Without its financial and moral support, this paper would hardly make its appearance on the academic public.

2 Nietzsche, F. 2006. The Will to Power. 127 (aphorism 253), Ludovici, A. M. (Trans.). New York: Barnes \& Noble, See also: Arendt, H. 2003. Responsibility and Judgment. Kohn, J. New York: Schocken Books, 63, 277.

${ }^{3}$ For our legitimate use of these two last Nietzschean expressions as having the same connotation, see: Arendt, H. 1977. The Life of the Mind. One/Thinking, McCarthy, M. (Ed.). New YorkSan Diego-London: Harcourt, 10-11.
} 
the transcendental subject—-the "beyond" that finds its place within the immanence of human conscience-does not man also forfeit his inner freedom? Does not this "death" mean that the categorical imperative loses its very source, i.e., its ratio essendi?

So, it seems that Nietzsche deconstructs at one stroke the most fundamental assumption underlying Western metaphysics and morality in their most important, albeit different, instances. But, even if Nietzsche repudiates their common originator, namely, Plato, he does not recognize the origin of this assumption in the way the faculty of thinking functions. Besides, this specific justification may well point to the fundamental affinity between Christianity and Kantianism. In Arendt's view, this basic assumption, that is, the Platonic doctrine of a true supersensible world is but a fallacy which had been established by virtue of its plausibility within the sphere of the thinking activity. In short, the Platonic teaching of the intelligible world's existence arose out of the elementary human experience of thinking's necessary withdrawal from the world of phenomena (including the physical existence of one who thinks). It is evident that the hypothesis of a supersensible world has played, under various forms, a most important role in the tradition of Western metaphysics and morality. This hypothesis is founded on the very thinking process which apparently outlived its thought-products in the way they had been formulated by Plato himself. ${ }^{4}$

From a political point of view, one of the most crucial fallacies of the thinking process - in the Platonic and, potentially, in every philosophical framework of reference-consists in looking at the multitude of men from the perspective of the philosopher whose activity is contemplation. An illustrative demonstration of the case is the Platonic cave allegory, wherein the multitude of men appears as a multitude of chained prisoners who are isolated from each other, without being capable of any conversation or joint action. ${ }^{5}$ In other words, the prisoners represent in the political field the philosopher's own contemplative isolation. And this existential analogy occurs independently of the differentiated ontological status of the shadows and the Idea of Good, the former being the object of each prisoner's sense perception, and the latter the object of the philosopher's intellect. Consequently, the Platonic ascent to the contemplation of the Good presupposes not only philosopher's alienation from the human world, but also considers its inhabitants under the terms of the philosophical activity and its inherent isolation. ${ }^{6}$

\footnotetext{
${ }^{4}$ For an elaborate account of these remarks, see: Arendt, H. 1977, op. cit., 23-26.

${ }^{5}$ Arendt, H. 2005. The Promise of Politics. Kohn, J (Ed.). New York: Schocken Books.

${ }^{6}$ For a further understanding of the meaning of isolation, as distinguished from solitude and loneliness, see Arendt, H. 2003, op. ct., 99. In this context, it is important to note that the word "isolation" alludes to the fact of the purposively conducted- on behalf of Plato- withdrawal of the philosopher from the multitude of prisoners and the virtually structured alienation of each prisoner from the same multitude. To be sure, and in modern terms, each prisoner may not be really isolated, but a lonely fellow in the midst of all the others. But, even if ancient political thought
} 
Now, to the extent that the philosopher has a body or, in other words, to the extent that he cannot withdraw definitely from the world altogether, the direct consequence of his philosophical venture is but the return to the cave of human affairs and the enforcement of his claim for isolation upon the human condition of plurality-cunningly transformed by Plato into the image of "the multitude of isolated prisoners." Finally, this enforcement is tantamount to an originally moral conceptualization of political rulership, "until the whole of the public realm is seen in the image of 'man writ large,' of the right order between man's individual capacities of mind, soul, and body."

Therefore, it seems that "the allegory of the cave is thus designed to depict not so much how philosophy looks from the viewpoint of politics, but how politics, the realm of human affairs, looks from the viewpoint of philosophy." 8 But, insofar as Platonic philosophy is not restricted to the contemplation of the "true world," but aims, by means of this very truth, to fabricate the "shadow-world" according to patterns best fitted to the moral status of the philosopher-inisolation, it seems evident that the allegory of the cave is also "designed to depict how politics looks from the viewpoint" of the philosopher's just soul, his inner moral order. In other words, Platonic teaching achieves the principal and traditional connection between philosophy, morality and isolation.

One may protest and support that we do not take into account the faracknowledged difference in principle between Greek, and thus also Platonic, strictly ethical, virtue-directed discussion of these matters and the Kantian deontological status of the Moralität. This is true. But our purpose here consists in revealing the nuclei of the Arendtian understanding of moral matters on the basis of her fundamental belief that "men, and not Man, inhabit the world." In Arendt's own terms, this discussion lacks an appropriate word to begin with. For moral matters, strictly speaking, refer to habits or customs. At any rate, morality, in Arendt's view, points to the tradition that starts with Socrates, and tries to formulate plausible answers to the "brutally elementary" question of what is right and wrong. This question goes beyond the categories of values or even virtues. ${ }^{9}$ For, in my opinion, Arendt seeks to overcome the notion of an

knows very well the group behavior of the mob, it is only natural that it did not go so far as to discover loneliness in its political dimensions: the phenomenon of "loneliness" is, in the Arendtian understanding, a strictly modern reality that characterizes the atomized mass individuals of the last century (see Arendt, H. 1994. The Origins of Totalitarianism. New York: Harcourt, 474-479).

${ }^{7}$ Arendt, H. 1998. The Human Condition. Chicago: University of Chicago Press, 237-238.

${ }^{8}$ Arendt, H. 2005, op. cit., 31.

${ }^{9}$ Arendt's depreciation of thinking in terms of values is well known (see Arendt, H. 2003, op. cit., 51). As far as virtues are concerned, Arendt's position is somehow equivocal. But all we can say now is that the notion of virtues alludes to character-an inner state of the individual which may be cultivated by means of repetition and examples, and which manifests itself in structured-on-this-particular-character deeds. This conviction constitutes an individual-directed way of 
"ought to act in such or such a way" being the basis of Platonic, Christian, and Kantian morality. ${ }^{10}$ To be true, there are some crucial instances when "someone ought not to have done what he did." But her seemingly paradoxical conclusion is: in order to avoid what you should not do, all you can say is that you cannot do it. If you say "I ought not to do it", you are not at all reliable. ${ }^{11}$

Anyway, apart from various philosophical attempts to understand and fabricate the political realm on the model of the existential condition of isolation and the moral status of the philosopher, as far as the strictly moral order of things is concerned there is one conclusion that seems obvious: from Plato onwards, morality requires that man escapes, as far as possible, from the market noise, that is, from the political-worldly affairs which are always realized under the condition of plurality. Speaking in Platonic terms, this happens because the contemplation of a "real" intelligible world "beyond" the human senses - the necessary precondition of the philosopher's moral commitment - demands the cessation of worldly activities. Therefore, it seems as though the absolute "beyond" and the alienated moral exercise go together. Nietzsche is right: the "beyond" is absolutely necessary for keeping our faith in traditional morality.

This moral estrangement usually takes the form of an open hostility to the political realm. But this is a sweeping statement and needs to be qualified.

An illustrative explanation of the precedent conclusion is the elucidation of the vague understanding of the so-called "spirit of Machiavellianism." To be

formulating the principle of the politically desirable harmony between polis' and individual's

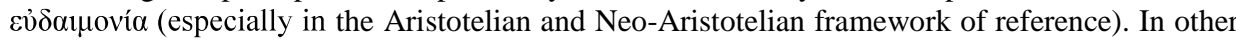
words, what is problematic about virtues is that, on the one hand, they are founded on some notion of the good ( $\dot{\alpha} \gamma \alpha \theta \dot{o} v)$ which, for Arendt, is absolutely irrelevant as far as morality an d politics are concerned; and that, on the other hand, virtues, by means of their external manifestation in the world of appearances, assume political qualities that have nothing to do with (a) greatness, the most appropriate principle of judging political action, and (b) the borderline political implications of thinking whereupon morality is to be found as a by-product. To be sure, virtuous persons, historical or fictional, may play the role of examples for moral judging. While thinking leads us to say "I cannot do this or that," judging comes to tell us that this or that is wrong, and you have a living example for it, Socrates, Jesus of Nazareth, or Sophie Scholl or Mahatma Gandhi.

${ }^{10}$ This "ought" may be found, as far as Plato is concerned, in the compulsory character of the Ideas that impose themselves upon voṽ in the form of "self-evident" truths that determine what is right and what is wrong on the moral level (see Arendt, H. 2003, op. cit., 278, note 10). Christianity and Kantianism, their radical differences notwithstanding, share their dealing with a newlydiscovered faculty, namely, the will. If we overlook for a moment will's spontaneous quality, that is, will's capacity to move us into action, what remains is a will that functions only under commands in the form of "you shalt," "you shalt not." To be true, these commands may be considered as the expression of God's will or the product of a moral law within me. And it is also true that Kant did not "look upon actions as obligatory because they are the commands of God, but" did "regard them as divine commands because we have an inward obligation to them" (Kant, I. 1965. Critique of Pure Reason, Smith, K. N. (Trans.). New York: St. Martin's Press, A819, 644; See also Arendt, H. 2003, op. cit., 66). But, the point of the matter is that Kant keeps the original Christian notion of obligation in t a c t .

${ }^{11}$ Arendt, H. 2003, op. cit., 45. 
sure, Machiavelli was the first who promoted a clear-cut distinction between morality (i.e., Christian) and politics. For Machiavelli, this distinction implied a differentiated appreciation of the meaning of the two spheres of life, namely, the private and the public realm. Prompted by this particular claim, and as far as the political life is concerned, he insisted that men "should learn how not to be good." By this, as Arendt argues, "he of course never meant that they should learn how to be evil."12 The point of the matter is that the negative description of statesmen's duty has overshadowed the basic Machiavellian understanding of politics under the criteria of performance, greatness and, by definition unselfish, care for one's country; that is, under the criteria of the venture that comes in sharp conflict with the Christian-moral exclusive care for the privacy and the health of one's soul. Our well-bred Christian understanding of things has, with respect to Machiavelli, the following implications: The Realpolitik spirit is unfairly connected with Machiavelli and considered as a synonym of "duplicity" and "cunning." And this occurs in absolute agreement with the Christian abhorrence of the public realm - the space of appearances par excellence, the space where plurality finds its proper place.

That morality appears here as a peculiar care-for-the-self, which is actualized only insofar as the self withdraws from the world, may sound strange to our Christian ears and our subsequent understanding of moral conduct. But, as Arendt reminds us, even the Christian love of the neighbor, apart from its essentially anti-political quality, is founded on love of one's self. In the same vein, if the self wishes to be good, then, he should not only disappear from the field of others' sight but also from his very inner sense of being a self: "Do not let your left hand know what your right hand is doing." 13

From Platonic Socrates (who does not know where the marketplace is) to the Kantian inhabitant of the supersensible Kingdom of Ends (where the "authentic self," the noumenal subject resides) morality, either under the form of virtuous ethics or deontology, resides in the existential condition of alienation from the common world — at least from its most elementary appearance, namely, the body.

To avoid misunderstandings: Someone could rightfully object that the Aristotelian conception of moral virtues provides for them a decent status in the human condition of plurality. Besides, the Aristotelian, and at the same time anti-Platonic, understanding of justice as essentially political reinforces the precedent assumption. However, if, according to the Aristotelian definition, human virtue is the perfect accomplishment of the है pyov which is appropriate to human nature, and if the basic differentia specifica of human nature is but voũs (among the mortal living beings), then man attains perfection insofar as he leads

\footnotetext{
${ }^{12}$ Arendt, H. 2006. Between Past and Future. Eight Exercises in Political Thought. London: Penguin, 108.

${ }^{13}$ Matthew 6, 3. See also Arendt, H. 1977a. The Life of the Mind. Two/Willing, McCarthy, M. (Ed.). New York-San Diego-London: Harcourt, 67.
} 
a purely philosophical way of life. In other words, the Aristotelian connection of ethics with the realm of human interactions does not exhaust the discussion on virtue as such. Consequently, the research which confines itself to strictly human affairs would be disappointing to the godlike and immortal part of the human soul. Besides, the pleasing-togod contemplation of Being presupposes that man transcends the mortal limits and obstacles. In other words, the excellent life finds itself again in a curious state of modest hostility to the common world of men and to the body of the thinking being. On the one hand, "the excellence of reason is a thing apart [i.e., from our composite nature]."14 On the other hand, while the citizen is in need of "many [i.e., external] things" in order to exercise in a reasonable way his moral virtues, "the man who is contemplating the truth needs no such [i.e., external] thing, at least with a view to the exercise of his activity; indeed they are, one may say, even hindrances, at all events, to his contemplation." 15 Indeed, the philosopher leads his theoretical life on the model of the completely isolated, indifferent to the human world and immobile life of the Aristotelian god. Besides, the traditional Greek ideal of self-sufficiency, considered as the definite measure of human virtue, finds in Aristotle and in Plato, the greatest expression only on the level of contemplation which is the only activity that takes place for its own sake. However, the greatness of Aristotle consists in the fact that he does not underestimate the "autonomous and authentically human [i.e., moralpolitical] way of life"16 and that he does not impose, in a Procrustean way, criteria of the excellent theoretical life upon the everyday condition of human plurality. Because even the philosopher, "in so far as he is a man and lives with a number of people, he chooses to do virtuous [i.e., moral-political in the Aristotelian sense] acts; he will therefore need such aids to living a human life." 17

In any case, traditional morality is not "written" in the Aristotelian spirit, even if Aristotle eventually considers-in agreement, at this point, with Platothe priority of the vita contemplativa over other more plural activities as a mat-

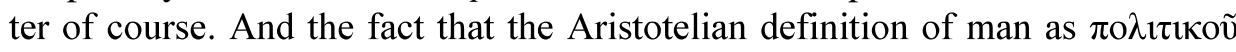
$\zeta \omega$ ov has been overshadowed by the most representative, even in the Aristoteli-

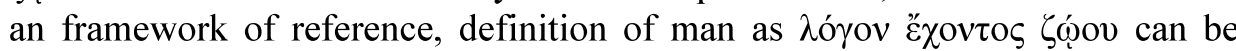
attributed to this crucial accord between the two greatest philosophers of Greek

\footnotetext{
14 Aristotle. 2009. The Nicomachean Ethics. Ross, D. (Trans.). Oxford: Oxford University Press, 1178a.

${ }^{15}$ Ibid., $1178 b$ (my emphasis).

${ }^{16}$ Arendt, H. 1998, op. cit., 13.

${ }^{17}$ Aristotle. 2009, op. cit., 1178b. See also Arendt, H. 2003, op. cit., 65: "To be sure, Aristotle too knows of the divine, which to him is the imperishable and the immortal, and he too thinks that man's highest virtue, precisely because he is mortal, consists in dwelling as much as possible in the neighborhood of the divine. But there is no prescription, no command, to this effect that could be obeyed or disobeyed. The whole question turns around the good life, which way of life is best for man, something obviously up to man to find out and to judge."
} 
political thought. Furthermore, there is no better illustration for contemplation's "victory" than the equally important fact that the Latin translation of the $\lambda$ ó $\gamma$ ov

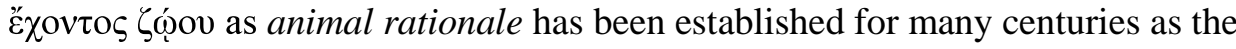
most valid definition of human nature. And it seems evident that this linguistic legacy has predominated over the political dimension of the Aristotelian concept of $\lambda$ ó ${ }^{\prime} \varsigma$ understood as a speech exercised in the in-between space of the human intercourse..$^{18}$

Now, let us turn our attention to the metaphysical background of the original connection between philosophy, morality and isolation: Platonic philosophy pretends to have discovered a standing point outside the world from where a complete view and objective evaluation of human activities could be possible; subsequently, this philosophical "Archimedean point" guarantees the capacity to define the human essence. Hence, Plato is the first to seek for a positively formulated, and universally valid, definition of human nature per se. In the Platonic context, only the philosopher can perfectly meet the definition of human nature; and this, to the extent that the philosopher's voũ s is capable of contem-

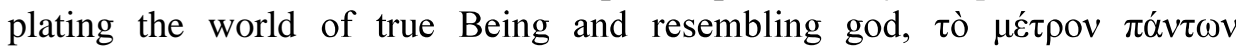
$\pi \rho \alpha \gamma \mu \alpha \dot{\tau} \omega v$ and the model of human behavior. If the Western tradition has sanctioned the Aristotelian definition in its Latin translation as the most valid definition of human nature, this is due to the Platonic reading of Aristotelian thought - the reading which is supported to a great extent by the very Aristotelian text and which overshadowed the political dimension of $\lambda o$ jos as speech exercised within the public sphere of life. Furthermore, not only the answer to the question about the essence of man does promote almost necessarily his dimension as a thinking being; the very question, in the way in which it is formulated, requires inevitably an answer that considers human being only in the condition of isolated singularity.

In other words, thinking activity, insofar as it concerns itself with human nature, defines it not only by means of thinking's very power, namely, the faculty of reason, but also by means of the peculiar-to-thinking condition of isolation. Mutatis mutandis, is it haphazard that the Rousseauistic revolution of the heart has delivered to the scaffold not only reason but the egotism that supposedly accompanies it?

So, in Arendt's view, philosophy of $\dot{\alpha} v \theta \rho \omega ́ \pi \varepsilon 1 \alpha \pi \rho \alpha \dot{\gamma} \mu \alpha \tau \alpha$, that is, thinking about human condition, has originally been established as an activity that examines Man as such and considers men in the plural as reproductions of the One and absolutely definable human nature. ${ }^{19}$ Accordingly, this very tradition understands Man only in terms of sheer isolation from the common world of men in the plural. Even in the Kantian conception of Man as Freedom, which is tantamount to defending man's capability of transcending, to some extent, the natu-

${ }^{18}$ Arendt, H. 1998, op. cit., 27.

${ }^{19}$ See especially Arendt, H. 2005, op. cit., 93-96. 
ral and historical dimensions of his existence, Man-and not men in pluralityis at the center of consideration. From a Nietzschean point of view, Kantian transcendental idealism is a "trap" no less dangerous than the classical Platonic realism. In terms of an understanding of Man in his singularity, the recourse to a decisive for the morality "beyond," even under the form of these concessions that pay their compliment to the immanence of human conscience (the lumen naturale of the Age of Enlightenment, namely, Rousseau's and Kant's "celestial voice" of conscience), will always be "absolutely necessary." Under these conditions, morality concerns Man, namely it concerns a human being only as long as he withdraws from the world of his fellowmen. In this case, morality is politically insignificant.

Now, under the influence of the modern collapse of absolute moral standards, whose emergence Nietzsche was the first who anticipated it in its full length, it may seem that there is no other way than our turning from the "beyond" to the bottomless Nietzschean cave until we meet an "Eichmann [or a Hitler] in every one of us"20 — with the clear danger that real Eichmann (or real Hitler) may prove unrecognizable in view of our so-called tremendous potentialities of accomplishing the greatest evil.

2.

Let us raise the question: What does Arendt think about morality and its relation to the common world? Arendt's answer is groundbreaking and antiphilosophical: We will be naïve if we keep on believing that Man, and not men, inhabits the earth. Consequently, "if we really believe-and I think we share this belief - that plurality rules the Earth," 21 the alienation from the human world, inherent in traditional morality, loses the ultimate source of its plausibility and justification.

To avoid misunderstandings: we do not question here the pluralistic character of the history of moral ideas. By the term "traditional morality," we mean the moral principles that determined the course of the Christian Western civilization for many centuries and were delivered down from generation to generation by means of the Christianized Roman trinity, namely, authority-traditionreligion. We have already described the originally Platonic experience behind this development. But the charter of traditional morality is, of course, the Ten Commandments. And a bothersome question arises: How can the Christian duty of obedience to the moral precept "Thou shalt not kill" be hostile to the plurality of the human world? There is perhaps no better explanation of Christian morality's hostility to the world than the instance of Apostle Paul, a founder of Christian Church. The commandment "thou shalt not kill" makes known to Paul the

\footnotetext{
${ }^{20}$ For an intense depreciation of such a "slogan," see Arendt, H. 2003, op. cit., 59. See also Arendt, H. 2006a. Eichmann in Jerusalem. A Report on the Banality of Evil. London: Penguin, 286.

${ }^{21}$ Arendt, H. 1979. "On Hannah Arendt." In: Hannah Arendt: The Recovery of the Public World. Hill, M. A. (Ed.). New York: St. Martin's Press, 305.
} 
very sin from which he tries to escape. There follows an extreme inner struggle, which expresses itself in Paul's assertion that "I do not do what I want, but I do the very thing I hate" 22 and is healed only by the intervention of Divine Grace. The ultimate conclusion is the following: "The very commandment which promised life proved to be death to me." ${ }^{\prime 23}$ The righteous man resembles a ghostlike creature, a "dead" man between living men, a man that obeys the moral command at the same time that his human flesh is thirsty for blood. The existential condition appropriate for him is, of course, total is olation.

Now, if the "true world" of philosophy and Christian religion has been abolished altogether, this is not the case with respect to the world of men who inhabit the Earth under the condition of plurality. For, if there is a fundamental belief in Arendt's work, it consists in the conviction that "plurality is the law of the earth". ${ }^{24}$ The term "plurality" alludes to the plurality of men, activities, objects, peoples, civilizations, and political communities. Arendt's approach seems to perform the promotion of a factual state of human dwelling to the validity of a principle that should regulate human intercourse. ${ }^{25}$

In the same vein, early Arendt's view that totalitarianism has brought men face to face with "radical evil" is not determined by an understanding of the latter in terms of "perverted ill will" in man (as Kant would argue). ${ }^{26}$ While the discussion of evil on the level of the agent had been virtually postponed until Arendt attended the Eichmann trial, it seems clear that evil alludes, as far as the consequences of its manifestation in the world are concerned, to the totalitarian exercise of mass murder of peoples with particular history and tradition. For, politically speaking, the distinctive quality of radical evil is not so much its "absoluteness" which is considered to be equivalent to the absence of mass murderers' personal motives whatsoever, but its anti-cosmic dimension and its terrifying potentiality of transforming the human condition of plurality into a mass of superfluous men. ${ }^{27}$

\footnotetext{
22 Paul. Epistles to Romans, 7, 15.

${ }^{23}$ Ibid., 9-10. This and the former quotation can be found in Arendt, H. 1977a, op. cit., 64-65.

${ }^{24}$ Arendt, H. 1977, op. cit., 19. We speak consciously about the existence, in Arendt's work, of a "fundamental belief" rather than of a philosophical axiom. If we accept that plurality is a philosophical axiom, we will hardly resist the temptation to consider Arendt as a philosopher and deduce the entirety of her thoughts from this supposedly foundational premise. I think that there is a widely open question with regard to the specific status of the concept "plurality" and its possible consideration as a factual condition and, at the same time, as a regulative principle (see below). But, as far as the relationship between plurality and philosophy is concerned, the truth of the matter is that plurality is the pre-philosophical precondition of thinking and philosophy. But this is a sweeping statement and stands in need of further qualification. I intend to elaborate all these specific questions in a forthcoming work.

${ }^{25}$ See footnote 24.

${ }^{26}$ Arendt, H. 1994, op. cit., 459.

${ }^{27}$ Ibid. See also Bernstein, R. J. 1996. Hannah Arendt and the Jewish Question. Cambridge and Massachusetts: MIT Press, 137-153.
} 
This objective, world-directed understanding of evil outlives the substitution of banality for radicalism on the level of the agent. Exercising her judgment on the "monstrous acts" of Eichmann, Arendt argues: "you supported and carried out a policy of not wanting to share the earth with the Jewish people and the people of a number of other nations - as though you and your superiors had any right to determine who should and who should not inhabit the world." ${ }^{28}$ Consequently, the plurality of nations assumes here the validity of a supra-cultural and intercultural principle by virtue of which every people has the right to inhabit the Earth. In this sense, the distinctive character of people is not guaranteed by means of war and struggle (as in Carl Schmitt's understanding) but only through people's coexistence and mutual intercourse.

Here emerges a thorny question: after remaining faithful in the existence of the world of men, is it possible to rescue our faith in morality from drowning, without recourse to an already "dead" absolute? And then, how could we ensure the reconciliation of morality to the world?

The modern collapse of traditional absolute moral standards, as conceptualized by Nietzsche and realized under the Nazi and Stalinist regimes, is founded on a groundbreaking inversion of Decalogue's basic commandments. ${ }^{29}$ So, these two regimes substituted the commandment "Thou shall kill" for "Thou shalt not kill." Not only murder was the fundamental "principle" of the totalitarian form of government insofar as it constitutes the outward manifestation of terror. At the same time, it ought to be interiorized in a fundamental axiom of mass murderers' so-called conscience. A suggestive instance of the axiom is, of course, Eichmann: "[...] and as for his conscience, he remembered perfectly well that he would have had a bad conscience only if he had not done what he had been ordered to-to ship millions of men, women, and children to their death with great zeal and the most meticulous care." ${ }^{30}$

In Arendt's view, the loss of authority of traditional moral standards means that "what perhaps hitherto had been of spiritual significance only for the few now has become a concern of one and all." ${ }^{31}$ In other words, and from a decisive moral point of view, what has become "a concern of one and all" is the very thinking activity. It is on the ground of this emancipation of thought that Arendt follows the "Socratic path"; 32 the ultimate reason for her choice lays in

\footnotetext{
${ }^{28}$ Arendt, H. 2006a, op. cit., 279.

${ }^{29}$ Arendt, H. 2003, op. cit., 54.

${ }^{30}$ Arendt, H. 2006a, op. cit., 25. It seems clear that Arendt speaks on Eichmann's "conscience" in a patently ironical tone.

31 Arendt, H. 2006, op. cit., 93.

32 The Arendtian path following the Socratic one is conspicuous almost throughout the Arendtian corpus. See especially Arendt, H. 2003, op. cit. Kant, prompted by a more specific and earlier emancipation of thought from religion, followed the same path, albeit with different implications and consequences. Besides, his emancipation of thought from religion differs from thought's emancipation from authority. In Arendt's view, authority was the last, and surely post-
} 
the fact that the Socratic path passes through the citizens' market place. Not only does early Socrates (Socrates of the aporetic dialogues) know where the market place is. By means of his own involvement, he also transforms it into a sphere of examining the most fundamental human issues. Therefore, Arendt's turn to Socrates does not consist in a nostalgic mental game. On the contrary, this turn is consistent with the Arendtian appreciation of plurality as the human condition par excellence. From this experience the most significant human concerns derive their meaning.

Under the criteria of the Socratic model, it is evident that the image of the Platonic philosopher's estrangement from human affairs is an inversion of Socrates' turning to the market place. Accordingly, the image of the undesirable but inevitable return of the Platonic philosopher to the cave is an inversion of the Socratic desired returning to the solitude of the harmonious dialogue with his very self. ${ }^{33}$ Furthermore, and in a particularly decisive way, while the Platonic philosopher's coming back presupposes the consideration of the human plurality under the terms of the existential condition of isolation, the Socratic return to privacy could be understood as the keeping-up of a dialogue. This dialogue begun earlier among the many but it is still maintained in the form of a soundless dialogue between him and himself, in the sphere of solitude. Solitude, to be sure, is an illusion. For "this Socratic two-in-one," as it manifests itself in the split-up of Socrates during the discussion with himself within the thinking activity, "heals the solitariness of thought; its inherent duality points to the infinite plurality which is the law of the earth." 34

This duality inherent in the thinking process, by virtue of its peculiar partaking in the plurality as law of the earth, conditions man as a thinking being against the possibility of committing the greatest evil. In one way or another, and politically speaking, the latter consists in the elimination of the plural terms under which life is given to us. Consequently, abstention from evil presupposes that the thinking process, by its very function, has already "installed" plurality into the immanence of human conscience. In a Kantian spirit, the thinking being cannot possibly want to eliminate the plural conditions of its very possibility, as these were offered to his mental life by the common world.

"Or, to put it in a more Socratic way [...] the reason why you should not kill, even under conditions where nobody will see you, is that you cannot possibly want to be together with a murderer. By committing murder you would deliver yourself to the company of a murderer as long as you live." ${ }^{35}$ In the last in-

Kantian, instance of the modern collapse of the trinity religion-tradition-authority (Arendt, $\mathrm{H}$. 2006, op. cit., 91-141). For Kant's conscious choice of the same route, see his 2006. Groundwork of Metaphysics of Morals. Gregor, M, J. Timmermann (Eds.). Cambridge: Cambridge University Press, 37.

${ }^{33}$ Arendt, H. 1977, op. cit., 188-189.

${ }^{34}$ Ibid., 187.

${ }^{35}$ See, for instance, Arendt, H. 2005, op. cit., 22. 
stance, it is evident that the metaphor of an "inner company" is clearly derived from the everyday experience within the company of our fellowmen. ${ }^{36}$ The solitary dialogue presupposes the dialogue with others ${ }^{37}$ and the emergence in the world of appearances. For "when people have lost contact with their fellow men as well as the reality around them [...], men lose the capacity of both experience and thought." ${ }^{38}$ Consequently, the thinking activity, in order to be actualized later in the private realm of solitude, presupposes the dialogical participation of the potentially thinking being in the world of men and the joint recognition of events in their sheer factuality. Let us insist on the model of Eichmann's "banality," which sheds light on the Arendtian understanding of thinking, albeit in a negative sense: "such remoteness from reality and such thoughtlessness can wreak more havoc than all the evil instincts taken together which, perhaps, are inherent in man - that was, in fact, the lesson one could learn in Jerusalem." ${ }^{39}$

To be sure, if the thinking process prevents us from doing evil, this is possible insofar as its actualization marks a withdrawal from the world altogether and ensures the preservation of its own harmony. ${ }^{40}$ This care for one's self and for the harmony of the soundless dialogue of thought remains highly subjective. ${ }^{41}$ Consequently, despite the existential dependence of the thinking being on the public dialogue, thinking activity remains, as far as its elementary care is concerned, hostile to the activities of the world of appearances. Besides, from the viewpoint of the world, "the dialogue with myself in solitude or with another self, even when conducted in the marketplace, shuns the multitude." ${ }^{\prime 2}$ In the final analysis, by posing before itself a stumbling block of negative nature, it does not strengthen world's defence against evil. For a change of the world requires men's acting-in-concert whose guiding principles are derived from men's capability of keeping mutual promises and not from the subjective and numerous personal, moral or other, convictions. ${ }^{43}$

\footnotetext{
${ }^{36}$ On the role of the metaphor in describing mental experiences see Arendt 1977, op. cit., 98 110.

${ }^{37}$ Arendt, H. 2003, op. cit., 279 (footnote 12): "[...] No one who knows how to think will ever again be able simply to obey and to conform, not because of a rebellious spirit but because of the habit of examining everything. In the Apology Socrates' last answer to the judges was I cannot give up examining. Why could not he do it in silence? The priority of dialegesthai over dianoeisthai."

${ }^{38}$ Arendt, H. 1994, op. cit., 474

${ }^{39}$ Arendt, H. 2006a, op. cit., 288 (my emphasis).

${ }^{40}$ That is the spirit of the Socratic statement "it would be better for me that my lyre or a chorus I direct were out of tune and loud with discord, and that most men should not agree with me and contradict me, rather than that I, being one, should be out of tune with myself and contradict myself" (Gorgias, op. cit., 482b-c). The translation comes from Arendt, H. 2003, op. cit., 90.

${ }^{41}$ Arendt, H. 2003, op. cit., 110.

${ }^{42}$ Arendt, H. 2003, op. cit., 103

${ }^{43}$ Arendt, H. 1972. Crises of the Republic. New York: Harcourt, Brace, Jovanovich, 51-102.
} 
If this is the case, how is reconciliation between morality and world possible? Paradoxically, such reconciliation occurs in the midst of political disasters and collapse of all these standards and criteria which establish a code of conduct according to which each one of us could preserve his dignity in everyday life.

"At these moments, thinking ceases to be a marginal affair in political matters. When everybody is swept away unthinkingly by what everybody else does and believes in, those who think are drawn out of hiding because their refusal to join is conspicuous and thereby becomes a kind of action." 44

The onslaught of totalitarianism was an example of political disaster. But, because of the existential dependence of thinking activity on the everyday dialogue with our fellowmen, we wonder if it is easy to refuse to support Hitler, while everybody around, friends and enemies, and for any reason, have complied overnight with his murderous commands. The resolution of this perplexity is twofold. On the one hand, the very thinking activity, as long as men think and hold steadfast to its exercise, offers man, by virtue of its support by memory, the experience of depth. Within this dark sphere, on the other hand, there lay two mysterious faculties that come to thinking being's aid, that rescue it from its helpless sudden isolation. While the will gives human being the capability of beginning something new by virtue of the fact that he "may have enough of origin within himself to understand without preconceived categories and to judge," $" 45$ the very judging faculty may inform him that this specific support of this "political" leader can very well make a murderer out of him.

What could emerge from this mysterious cooperation of man's mental faculties is but a conduct which becomes a living reality that promises the preservation of our common world.

ABOUT THE AUTHOR — PhD, postgraduate student of moral philosophy, affiliation: Department of Philosophy, National and Kapodistrian University of Athens, School of Philosophy, Pedagogy and Psychology, Secretariat Panepistimiopolis, 15784 Ilissia (3nd floor), Greece.

E-mail: georgepap1407@yahoo.gr

\footnotetext{
${ }^{44}$ Arendt, H. 1977, op. cit., 192.

${ }^{45}$ Arendt, H. 19942. Essays in Understanding, 1930-1954. Kohn, J. (Ed.). New York: Schocken Books, 321-322.
} 